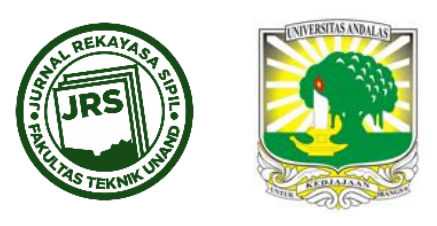

\title{
KARAKTERISTIK MORTAR DENGAN CAMPURAN ABU KERANG LOKAN DALAM RENDAMAN NACL
}

\author{
NELVIA ADI SYAFPOETRI ${ }^{1}$, ZULFIKAR DJAUHARI $^{2}$, MONITA OLIVIA $^{3}$ \\ ${ }^{1}$ Mahasiswa Pascasarjana Jurusan Teknik Sipil Fakultas Teknik Universitas Riau \\ (₫nelvia.adisyafpoetri@grad.unri.ac.id) \\ ${ }^{2}$ Dosen Jurusan Teknik Sipil Fakultas Teknik Universitas Riau (zulfikar.djauhari@lecturer.unri.ac.id) \\ ${ }^{3}$ Dosen Jurusan Teknik Sipil Fakultas Teknik Universitas Riau (monita.olivia@lecturer.unri.ac.id)
}

Naskah diterima : 20 April 2018. Disetujui: 14 Juli 2018. Diterbitkan : 14 Juli 2018

\begin{abstract}
ABSTRAK
Kulit kerang merupakan bahan yang dapat digunakan sebagai bahan pengganti agregat kasar, pengganti pasir, filler, dan sebagai bahan pengganti semen. Kandungan $\mathrm{CaO}$ dari kulit kerang berpotensi untuk meningkatkan kekuatan beton dan memperbaiki sifat-sifat beton. Pada penelitian ini abu dari kulit kerang lokan digunakan sebagai bahan tambah atau filler pada mortar dalam rendaman $\mathrm{NaCl}$. Kulit kerang lokan dibakar, dihaluskan dan disaring menggunakan saringan no.200 untuk mendapatkan ukuran partikel yang halus sehingga dapat memberikan reaksi pozzolanik yang lebih baik dan lebih mudah untuk mengisi pori pada pasta semen. Variasi penggunaan abu kulit kerang lokan sebagai bahan tambah atau filler adalah $0 \%, 5 \%$, dan $10 \%$. Proses perawatan benda uji adalah 28 hari perendaman air biasa dan dilanjutkan dengan perendaman dalam larutan $\mathrm{NaCl}$. Tahap pengujian yaitu pengujian kuat tekan, pengujian porositas, dan perubahan berat. Hasil pengujian menunjukkan bahwa penambahan abu kulit kerang lokan dapat meningkatkan kekuatan beton dan kinerja beton. Mortar dengan penambahan abu kulit kerang lokan sebanyak 5\% dan 10\% memiliki kekuatan tekan yang tinggi, porositas rendah dan perubahan berat kecil dibandingkan mortar $0 \%$. Diperoleh nilai optimum dari mortar dengan penambahan abu kulit kerang lokan sebanyak $5 \%$ dalam rendaman $\mathrm{NaCl}$.
\end{abstract}

Kata kunci : durabilitas, laut, kerang lokan, mortar

\section{PENDAHULUAN}

Lingkungan laut merupakan lingkungan yang memiliki sifat korosifitas yang agresif dan menyebabkan kerusakan pada beton. Interaksi fisik dan kimia banyak terjadi di lingkungan laut dan bekerja sama dalam merusak beton. Lingkungan yang agresif erat kaitannya dengan durabilitas yang merupakan salah satu karakteristik material konstruksi yang penting untuk diperhatikan. Di lingkungan yang agresif, sifat durabilitas dari material yang digunakan akan dihadapkan pada permasalahan seperti serangan ion sulfat dan ion klorida yang terkandung pada air laut (Olivia, 2009). Kedua ion ini berbahaya untuk beton karena dapat

DOI : https://doi.org/10.25077/jrs.14.1.63-72.2018

Attribution-NonCommercial 4.0 International. Some rights reserved 
menimbulkan korosi tulangan baja di bagian dalam beton. Ion-ion juga dapat menimbulkan korosi pada beton itu sendiri dengan menyerang kalsium yang terkandung dalam beton. Zona pasang surut dan percikan adalah lingkungan laut yang paling ekstrim mengalami serangan pada beton (Olivia, 2009). Degradasi permukaan dengan adanya garam dan perbedaan suhu yang terus menerus dari lingkungan air laut dapat meningkatkan porositas beton dan mempengaruhi daya tahan (Olivia, 2011).

Kerang merupakan salah satu hasil komoditi laut yang banyak dimanfaatkan dalam kehidupan sehari-hari. Sebagian besar pemanfaatan kerang belum dilakukan secara maksimal dan terbatas pada daging kerang untuk dikonsumsi dan pemanfaatan kulit kerang sebagai bahan baku kerajinan serta pakan ternak. Penggunaan kulit kerang sebagai bahan campuran beton telah banyak digunakan. Hal ini disebabkan oleh adanya kandungan $\mathrm{CaO}$ yang cukup tinggi pada kulit kerang (Siregar, 2009). Berbagai jenis kerang seperti kerang darah, tiram, periwinkle shells, remis, scallop, crepidula shells, dan conk shells dapat digunakan sebagai pengganti pasir, pengganti agregat kasar, filler, dan sebagai pengganti semen. Penelitian oleh Safi et al (2015) menyimpulkan bahwa pencampuran limbah kulit kerang tidak menyebabkan pengurangan nilai kuat tekan yang signifikan karena ikatan antara kulit kerang dan pasta semen sudah baik. Menurut Lertwattanaruk et al (2012) abu kulit kerang dapat diaplikasikan sebagai pengganti semen dalam campuran mortar dan dapat memperbaiki kemampuan kerja pada pasangan bata dan plesteran mortar. Potensi penggunaan berbagai jenis kerang misalnya kerang lokan untuk beton di lingkungan laut perlu diteliti lebih lanjut. Oleh karena itu, penelitian ini bertujuan untuk mempelajari pengaruh penambahan abu kulit kerang lokan dalam larutan $\mathrm{NaCl}$ yang diukur dengan kekuatan tekan, porositas dan perubahan berat.

\section{STUDI LITERATUR}

Menurut SNI-03-2847-2002, pengertian beton adalah campuran antara semen Portland atau semen hidraulik lainnya, agregat halus, agregat kasar, dan air, dengan atau tanpa bahan tambahan yang membentuk masa padat. Menurut Mulyono (2004), beton adalah sekumpulan interaksi mekanis dan kimiawi dari material penyusunnya yang terdiri dari semen hidrolik (portland cement), agregat kasar, agregat halus, air dan bahan tambah (admixture). Penggunaan beton pada struktur bangunan masih menjadi pilihan utama dikarenakan sifatnya yang mampu memikul beban yang berat serta tahan terhadap temperatur yang tinggi. Kekuatan dan daya tahan (durabilitas) beton dipengaruhi oleh kualitas semen, proporsi semen terhadap campuran, kekuatan dan kebersihan agregat, interaksi atau adhesi antara pasta semen dengan agregat, pencampuran yang cukup dari bahan-bahan pembentuk beton, penempatan dan pemadatan beton yang benar, dan kandungan klorida tidak melebihi 0,15\% dalam beton yang diekspos dan $1 \%$ bagi beton yang tidak diekspos (Mulyono, 2004).

Durabilitas adalah kemampuan beton dalam menghadapi lingkungan sekitarnya selama masa layan tanpa adanya penurunan kualitas karena adanya perubahan cuaca, serangan kimia maupun abrasi (Olivia, 2011). Kekuatan dan durabilitas beton dipengaruhi oleh perbandingan campuran, mutu dan bahan penyusun, metode pelaksanaan, temperatur, dan perawatan. Durabilitas berkaitan dengan kinerja beton dalam jangka panjang. Artinya, jika beton mampu bertahan dalam waktu yang cukup panjang tanpa adanya pengurangan kualitas beton itu sendiri, maka beton tersebut dikatakan baik atau tahan. Kualitas beton mengendalikan durabilitas beton itu sendiri di lingkungan agresif seperti lingkungan sulfat, lingkungan asam, dan lingkungan air laut. 
Air laut mengandung ion klorida yang cukup tinggi. Ion klorida bersifat agresif terhadap struktur beton (Aveldaño \& Ortega, 2011). Kandungan klorida yang tinggi dapat mengakibatkan kerusakan pada beton. Kerusakan yang terjadi akibat adanya reaksi antara air laut yang agresif yang terpenetrasi ke dalam beton dengan senyawa-senyawa di dalam beton yang mengakibatkan beton kehilangan sebagian massa, kehilangan kekuatan dan kekakuannya serta mempercepat proses pelapukan (Mehta \& Monteiro, 2006).

Salah satu cara untuk meningkatkan durabilitas beton di lingkungan laut adalah dengan pemanfaatan kulit kerang (Olivia, 2011). Kerang adalah hewan air yang bertubuh lunak (moluska), tidak bersegmen, terbungkus oleh mantel yang terbuat dari jaringan khusus, dan umumnya dilengkapi dengan kelenjar-kelenjar yang dapat menghasilkan cangkang. Kerang merupakan salah satu komoditi perikanan yang telah lama dibudidayakan sebagai salah satu usaha sampingan masyarakat pesisir. Berdasarkan data Statistik Perikanan Tangkap Indonesia, produksi kerang di Indonesia pada tahun 2010 mencapai 34.929 ton (DJPT, 2011). Produksi kerang-kerangan di Indonesia yang cukup besar tentunya akan menghasilkan limbah kulit kerang yang besar pula. Sejauh ini, pemanfaatan kulit kerang adalah sebagai pakan ternak, pembuatan terasi, kerupuk, bahan baku pembuatan kosmetik dan kerajinan tradisional (Permana, 2008).

Abu kulit kerang merupakan abu yang dihasilkan dari pembakaran kulit kerang yang kemudian dihaluskan, abu ini dapat digunakan sebagai bahan campuran atau tambahan pada pembuatan beton. Penambahan abu kulit kerang yang homogen akan menjadikan campuran beton yang lebih reaktif. Abu kulit kerang mengandung senyawa kimia yang bersifat pozzolan, yaitu mengandung zat kapur $(\mathrm{CaO})$, alumina dan senyawa silika sehingga berpotensi untuk digunakan sebagai bahan baku beton alternatif. Adapun komposisi kimia abu kulit kerang adalah 66,70 \% $\mathrm{CaO}, 0,39 \% \mathrm{SiO}_{2}, 0,02 \% \mathrm{Fe}_{2} \mathrm{O}_{3}$, dan 0,02\% $\mathrm{Al}_{2} \mathrm{O}_{3}$ (Olivia, 2016). Senyawa $\mathrm{CaO}$ berfungsi sebagai penambah kekuatan pada semen. Kadar $\mathrm{CaO}$ berpengaruh kepada kandungan $\mathrm{C}_{3} \mathrm{~S}, \mathrm{C}_{2} \mathrm{~S}, \mathrm{C}_{3} \mathrm{~A}$ dan $\mathrm{C}_{4} \mathrm{AF}$. Dimana $\mathrm{C}_{3} \mathrm{~S}$ pada semen berpengaruh pada kekuatan pada umur awal beton, $\mathrm{C}_{2} \mathrm{~S}$ pada semen berpengaruh terhadap kekuatan ketika beton telah mencapai umur kematangannya, $\mathrm{C}_{3} \mathrm{~A}$ pada semen berpengaruh kepada pelepasan panas hidrasi pada beton dan $\mathrm{C}_{4} \mathrm{AF}$ memberikan warna pada semen (Neville, 2011).

Supriani (2013) melakukan penelitian mengenai pengaruh umur beton terhadap kuat tekan dengan penambahan abu cangkang lokan menunjukkan bahwa terjadi peningkatan kekuatan beton pada umur 28 hari dengan variasi $5 \%$ penambahan abu cangkang lokan. Putra (2014) mengenai pemanfaatan limbah ampas tebu dan kulit kerang sebagai bahan subtitusi semen pada beton $\mathrm{K} 225$ dalam rendaman $\mathrm{NaCl}$ menunjukkan bahwa penambahan campuran tersebut dapat membuat beton tahan terhadap rendaman $\mathrm{NaCl}$. Penelitian oleh Olivia (2016) mengenai penggunaan kerang lokan dan kerang darah sebagai bahan pengganti semen menunjukkan bahwa dengan mensubtitusi semen sebanyak $4 \%$, beton dengan campuran abu kulit kerang lokan memiliki kekuatan tekan yang lebih baik daripada beton yang menggunakan campuran abu kulit kerang darah.

\section{METODOLOGI PENELITIAN}

Semen yang digunakan adalah semen OPC (Ordinary Portland Cement). Agregat halus berasal dari daerah Bangkinang. Ukuran butiran (gradasi) yang dipakai adalah lewat saringan 1,190 mm (saringan No. 16). Hasil pengujian karakteristik agregat halus meliputi $2.65 \%$ berat jenis, 4.07 modulus kehalusan, $1.42 \%$ kadar air, dan $0.95 \%$ kadar lumpur. Abu kulit kerang lokan yang digunakan diolah terlebih dahulu sebelum dijadikan sebagai bahan tambah pada campuran mortar. Kulit kerang lokan dibersihkan dan kemudian dibakar di 
tungku pembakaran batu bata. Proses pengolahan abu kulit kerang dapat dilihat pada Gambar 1. Kulit kerang lokan yang telah dibakar kemudian dihaluskan dan disaring menggunakan saringan no. 200. Selanjutnya dilakukan pengujian karakteristik kimia bubuk kulit kerang yang bertujuan untuk mengetahui kadar senyawa pozzolanik yang terkandung dalam bubuk kulit kerang yang akan digunakan sebagai campuran mortar sesuai dengan standar (ASTM C 618). Penelitian terdahulu oleh Syafpoetri (2013) diperoleh kandungan $\mathrm{CaO}$ pada kulit kerang darah adalah 55.10\% dan Mifshella (2014) sebesar 51.56\%. Penelitian berbeda oleh Oktaviani (2016) kandungan $\mathrm{CaO}$ kerang darah adalah $51.91 \%$ dan kerang lokan $67.70 \%$. Hasil pengujian karakteristik abu kulit kerang lokan pada penelitian ini dapat dilihat pada Tabel 1 dengan kandungan nilai $\mathrm{CaO}$ sebesar $56.28 \%$. Perbedaan kandungan $\mathrm{CaO}$ pada berbagai jenis kerang ini dapat disebabkan oleh pengaruh suhu dalam proses pembakaran (Mo et al 2018).

Benda uji berupa mortar ukuran 5 × 5 × $5 \mathrm{~cm}$. Variasi penggunaan abu kulit kerang lokan sebagai bahan tambah atau filler adalah $0 \%, 5 \%$, dan $10 \%$. Komposisi bahan yang digunakan mengacu pada SNI 06-6825-2002 yaitu perbandingan antara semen, pasir dan air adalah 1:2,75:0,55. Untuk setiap 6 benda uji ukuran 5x5x5 cm dibutuhkan $500 \mathrm{gr}$ semen, $1375 \mathrm{gr}$ pasir, $242 \mathrm{ml}$ air, serta penambahan $25 \mathrm{gr}$ dan 50 gr untuk variasi $5 \%$ dan $10 \%$ abu kulit kerang lokan. Proses pembuatan benda uji adalah dengan mencampurkan seluruh bahan yang sudah disiapkan dan diaduk menggunakan mixer, kemudian dimasukkan ke dalam cetakan lalu dibiarkan selama 24 jam. Selanjutnya dilakukan proses perawatan dengan merendam benda uji selama 28 hari dan dilanjutkan dengan perendaman benda uji pada larutan $\mathrm{NaCl}$ selama 28 hari. Kadar $\mathrm{NaCl}$ yang digunakan adalah $5 \%$. Tahap pengujian yaitu pengujian kuat tekan (SNI 06-6825-2002), pengujian porositas (ASTM C642), dan perubahan berat dalam larutan (ASTM C267).
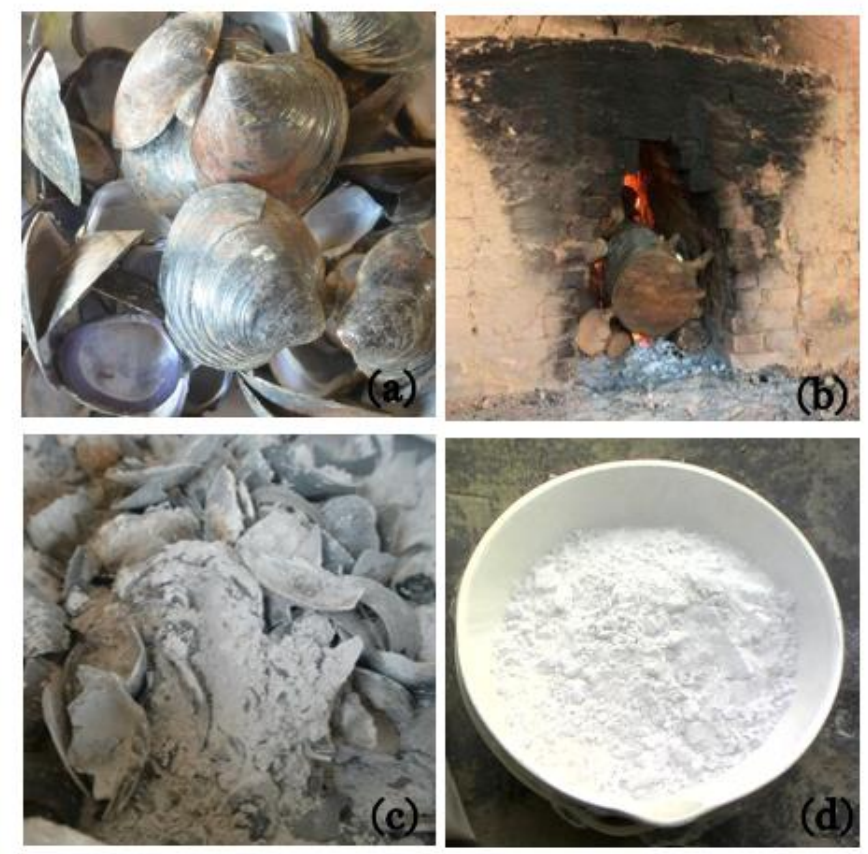

Gambar 1. Kulit kerang (a) Kulit kerang setelah dibersihkan; (b) Pembakaran kulit kerang;

(c) Kulit kerang setelah dibakar; (d) Kulit kerang setelah dihaluskan dan disaring 
Tabel 1. Karakteristik abu kulit kerang lokan

\begin{tabular}{llll}
\hline No. & Parameter Uji & Satuan & Hasil Analisa \\
\hline 1. & $\mathrm{CaO}$ & $\%$ & 56.28 \\
\hline 2. & $\mathrm{SiO}_{2}$ & $\%$ & 3.06 \\
\hline 3. & $\mathrm{MgO}$ & $\%$ & 1.19 \\
\hline 4. & $\mathrm{Fe}_{2} \mathrm{O}_{3}$ & $\%$ & 0.74 \\
\hline 5. & $\mathrm{SO}_{3}$ & $\%$ & 0.30 \\
\hline 6. & $\mathrm{Al}_{2} \mathrm{O}_{3}$ & $\%$ & 1.27 \\
\hline
\end{tabular}

\section{HASIL DAN PEMBAHASAN}

\subsection{Pengujian Kuat Tekan}

Pengujian kuat tekan mortar dilakukan pada umur 28 hari perendaman air biasa serta 7 dan 28 hari perendaman $\mathrm{NaCl}$. Kuat tekan pada 28 hari perendaman air biasa menjadi kuat tekan untuk hari ke-O. Hasil pengujian kuat tekan dapat dilihat pada Gambar 2.

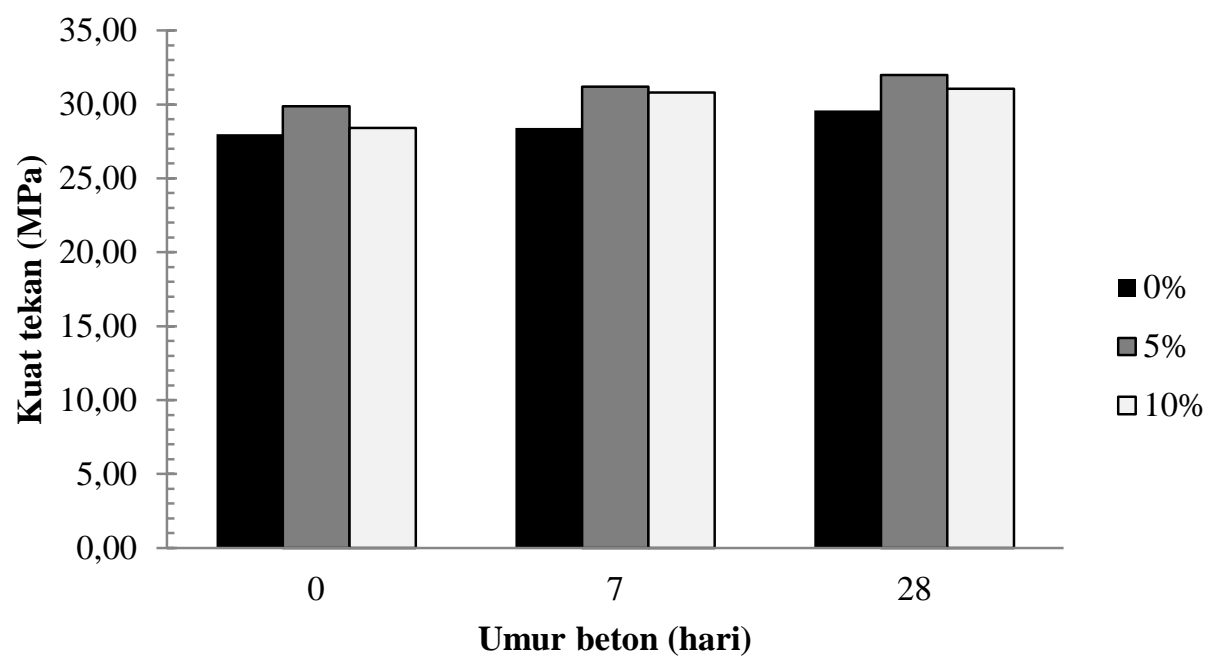

Gambar 2. Grafik kuat tekan kondisi statis

Seiring bertambahnya umur mortar terjadi peningkatan kekuatan tekan pada semua jenis mortar. Hal ini menunjukkan bahwa proses hidrasi berjalan dengan baik. Mortar dengan penambahan $5 \%$ abu kulit kerang memiliki nilai kuat tekan yang lebih tinggi dari pada mortar $0 \%$ dan 10\%. Mortar dengan penambahan 5\% abu kulit kerang pada umur 28 hari dalam rendaman $\mathrm{NaCl}$ memiliki nilai kuat tekan sebesar $32 \mathrm{MPa}$. Hal ini menunjukkan bahwa penambahan abu kulit kerang lokan dapat menambah kekuatan tekan pada beton. Tingginya kuat tekan mortar bubuk kulit kerang dibanding mortar OPC dipengaruhi oleh penambahan bubuk kulit kerang sebagai filler yang menjadikan mortar lebih kedap. Semakin kedap mortar, maka kuat tekan juga akan semakin baik. Penelitian oleh Kuo et al (2013) menunjukkan persentase penggunaan kerang sebesar 5\% lebih disarankan agar menghindari penurunan pada nilai kuat tekan. Persentase penggantian yang lebih besar dari $15 \%$ dapat mengurangi kekuatan, meningkatkan permeabilitas dan porositas beton (Othman et al., 2013).

Pada perendaman di larutan $5 \% \mathrm{NaCl}$, mortar OPC dan mortar dengan campuran abu kulit kerang memiliki kuat tekan yang terus meningkat. Menurut Suryavanshi et al, (1995) 
senyawa $\mathrm{C}_{3} \mathrm{~A}$ pada semen portland memiliki peran yang dominan pada proses pengikatan ion klorida. Proses hidrasi semen akan menghasilkan kalsium hidroksida $\left(\mathrm{Ca}(\mathrm{OH})_{2}\right)$. $\left(\mathrm{Ca}(\mathrm{OH})_{2}\right)$ yang bereaksi dengan $2 \mathrm{NaCl}$ akan menghasilkan $\mathrm{CaCl}_{2}+2 \mathrm{NaOH}$. CaCl akan bereaksi dengan $\mathrm{C}_{3} \mathrm{~A}$ membentuk kalsium klorualuminat $\left((3 \mathrm{CaO}) \mathrm{Al}_{2} \mathrm{O}_{3} \cdot \mathrm{CaCl}_{2} \cdot 10 \mathrm{H}_{2} \mathrm{O}\right)$ atau yang disebut dengan garam friedel. Garam friedel ini menempati volume yang besar setelah kristalisasi pada pori-pori daripada senyawa-senyawa yang digantikan tempatnya. Garam friedel cukup menguntungkan bagi kuat tekan karena dapat mengisi pori-pori pada pasta sehingga dapat menyebabkan kuat tekan bertambah tinggi (Adam, 2014).

\subsection{Pengujian Porositas}

Pengujian porositas mengacu pada ASTM C642-90 dengan tujuan untuk mengetahui nilai porositas yaitu ukuran dari ruang kosong di antara material dan merupakan fraksi dari volume ruang kosong terhadap total volume suatu mortar. Pengujian porositas ini dilakukan pada umur 0,7 dan 28 hari setelah mortar mengalami perendaman di dalam air biasa dan $\mathrm{NaCl}$.

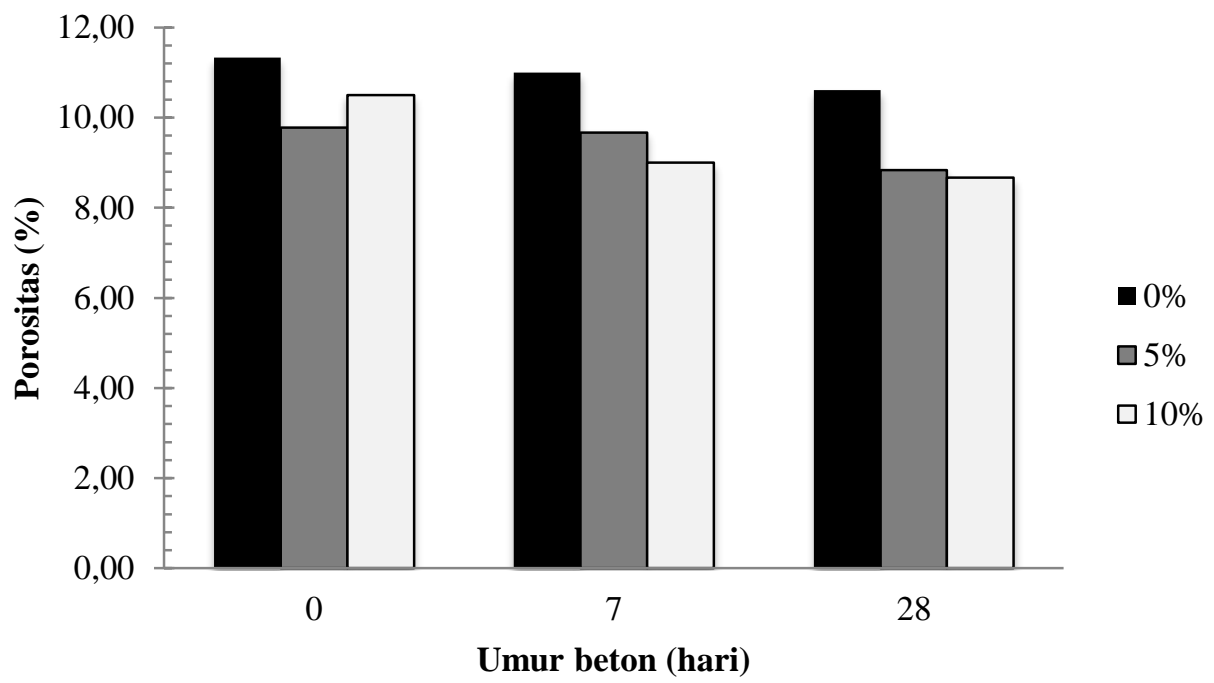

Gambar 3. Grafik porositas kondisi statis

Gambar 3 menunjukkan bahwa terjadi penurunan nilai porositas seiring dengan bertambahnya umur perendaman. Nilai porositas mortar $0 \%$ lebih tinggi dibandingkan dengan porositas mortar dengan campuran 5\% dan 10\% abu kulit kerang lokan. Penurunan nilai porositas mortar OPC dan mortar dengan campuran abu kulit kerang mengindikasikan bahwa kualitas mortar meningkat seiring dengan bertambahnya waktu perendaman. Hal ini sejalan dengan semakin bertambahnya nilai kuat tekan mortar OPC dan mortar dengan campuran abu kulit kerang selama bertambahnya waktu. Penelitian oleh Othman (2013) menunjukkan porositas beton akan mengalami penurunan seiring dengan peningkatan persentase penggantian abu kulit kerang dalam beton.

\subsection{Pengujian Perubahan Berat}

Pengujian perubahan berat berdasarkan ASTM C267 yang akan dilakukan dengan proses penimbangan berat benda uji pada umur 0, 7, dan 28 hari. Persentase kehilangan atau peningkatan berat mortar dapat dihitung dengan rumus berikut 
Perubahan berat, $\%=(\mathrm{W}-\mathrm{C}) \times 100 \%$

dengan:

$\mathrm{C}=$ berat benda uji (gram)

$\mathrm{W}=$ berat benda uji setelah direndam (gram)

Secara umum, Tabel 2 menunjukkan bahwa belum ada perubahan berat secara signifikan selama proses perendaman. Mortar dengan penambahan abu kulit kerang lokan 5\% memiliki perubahan berat dan penurunan perubahan berat yang kecil dibandingkan dengan mortar $0 \%$ dan 10\%. Hal ini berhubungan dengan nilai kuat tekan beton yang tinggi dan nilai porositas yang rendah. Dengan adanya proses hidrasi yang berjalan dengan baik dan proses pelepasan kapur dari campuran abu kulit kerang sehingga berfungsi untuk menutup pori mortar dan mencegah pelepasan partikel-partikel dari senyawa mortar tersebut.

Kulit kerang memiliki kandungan $\mathrm{CaO}$ yang tinggi berpotensi untuk dikembangkan sebagai bahan tambah alternatif untuk penggunaan beton di lingkungan laut. Penambahan abu kulit kerang dapat meningkatkan durabilitas beton dengan persentase penambahan tidak lebih dari $15 \%$ dan dapat diaplikasikan pada beton non struktural. Pemanfaatan kulit kerang selain dapat digunakan sebagai bahan baku alternatif juga dapat membantu dalam melestarikan lingkungan dengan mengurangi limbah dari kulit kerang tersebut.

Tabel 2. Perubahan berat kondisi perendaman statis

\begin{tabular}{cccc}
\hline \multirow{2}{*}{$\begin{array}{c}\text { Hari } \\
\text { ke- }\end{array}$} & $\begin{array}{c}\text { Variasi 0\% } \\
\text { rata benda } \\
\text { uji (gr) }\end{array}$ & $\begin{array}{c}\text { Berat rata-rata } \\
\text { setelah } \\
\text { direndam (gr) }\end{array}$ & $\begin{array}{c}\text { Perubahan } \\
\text { berat (\%) }\end{array}$ \\
\hline 0 & 279.33 & 279.33 & 0.00 \\
\hline 7 & 280.67 & 280.33 & 0.33 \\
\hline 28 & 282.00 & 281.33 & 0.67 \\
\hline \multirow{3}{*}{$\begin{array}{c}\text { Hari } \\
\text { ke- }\end{array}$} & $\begin{array}{c}\text { Berat rata- } \\
\text { rata benda } \\
\text { uji (gr) }\end{array}$ & $\begin{array}{c}\text { Berat rata-rata } \\
\text { setelah }\end{array}$ & $\begin{array}{c}\text { Perubahan } \\
\text { direndam (gr) }\end{array}$ \\
\hline 0 & 269.00 & 269.00 & 0.00 \\
\hline 7 & 272.00 & 272.00 & 0.00 \\
\hline 28 & 269.00 & 268.67 & 0.33 \\
\hline \multirow{3}{*}{$\begin{array}{c}\text { Hari } \\
\text { ke- }\end{array}$} & $\begin{array}{c}\text { Berat rata- } \\
\text { rata benda } \\
\text { uji (gr) }\end{array}$ & $\begin{array}{c}\text { Berat rata-rata } \\
\text { setelah }\end{array}$ & $\begin{array}{c}\text { Perubahan } \\
\text { direndam (gr) }\end{array}$ \\
\hline 0 & 286.00 & 286.00 & 0.00 \\
\hline 7 & 287.33 & 287.00 & 0.33 \\
\hline 28 & 283.33 & 283.00 & 0.33 \\
\hline 0
\end{tabular}

\section{KESIMPULAN DAN SARAN}

Pada penelitian ini, abu kulit kerang lokan digunakan sebagai filler atau bahan tambah pada campuran mortar dalam rendaman $\mathrm{NaCl}$. Secara umum, penambahan abu kulit kerang menunjukkan perbaikan sifat-sifat mortar yang direndam dalam larutan $\mathrm{NaCl} 5 \%$ hingga 28 hari. Penambahan abu kulit kerang pada mortar sebanyak 5\% memberikan nilai 
kekuatan tekan tertinggi, porositas paling rendah dan perubahan berat lebih kecil dibandingkan dengan benda uji mortar dengan penambahan kulit kerang $10 \%$ dan tanpa kulit kerang ( $0 \%)$. Hal ini disebabkan karena proses hidrasi berjalan dengan baik serta ikatan antara semen dan abu kulit kerang pada persentase penambahan $5 \%$ juga berjalan dengan baik. Akan tetapi, mortar dengan abu kulit kerang $10 \%$ juga menunjukkan nilai porositas lebih rendah dibandingkan mortar menggunakan 5\% abu kulit kerang dan OPC. Perbedaan porositas ini dapat terjadi karena penambahan abu kulit kerang membuat beton menjadi kedap dan menutup pori mortar. Mortar yang menggunakan abu kulit kerang sebesar $10 \%$ mengalami perubahan berat lebih rendah dibandingkan mortar OPC tanpa kulit kerang. Secara umum dapat disimpulkan bahwa penambahan kulit kerang sebesar 5$10 \%$ dapat memperbaiki sifat-sifat kuat tekan, porositas dan kepadatan beton.

Untuk hasil yang lebih baik lagi perlu dilakukan penelitian lanjutan dengan umur perendaman yang lebih lama serta variasi media rendaman yang berbeda.

\section{UCAPAN TERIMAKASIH}

Penulis ingin mengucapkan terima kasih kepada Wilujeng Purwanti atas bantuan dan kerjasamanya selama proses pengerjaan dan pengujian di Laboratorium.

\section{DAFTAR PUSTAKA}

Adam, N. A. ST. (2014). Pengaruh Penambahan Natrium Klorida (NaCl) Terhadap Waktu Ikat, Kuat Tekan Mortar dan Pasta. Universitas Hasanudin.

Aveldaño, R. R., \& Ortega, N. F. (2011). Characterization of concrete cracking due to corrosion of reinforcements in different environments. Construction and Building Materials, 25, 630-637.

Direktorat Jenderal Perikanan Tangkap. (2011). Statistika Perikanan Tangkap Indonesia 2010. Kementrian Perikanan Dan Kelautan Indonesia. Direktorat Jenderal Perikanan Tangkap. Jakarta.

Kuo, Wen-ten., Wang, Her-Yung., Shu, Chun-Ya., \& Su, De-Sin. (2013). Engineering properties of controlled low-strength materials containing waste oyster shells. Construction and Building Materials, 46, 128-133.

Lertwattanaruk, P., Makul, N., Siripattarapravat, C. (2012). Utilization of ground waste seashells in cement mortars for masonry and plastering. Journal of Environmental Management, 111, 133141.

Mehta, P. K., \& Monteiro, P. J. M. (2006). Concrete: Microstructure, Properties, and Materials. McGraw-Hill.

Mifshella, Annisa Arifandita. (2014). Sifat Mekanis Beton Kulit Kerang ( Anadara grandis ) Sifat Mekanis Beton Kulit Kerang. Universitas Riau

Mo, H.K., et al. (2018). Recycling of seashell waste in concrete : A Review. Construction and Building Materials, 162, 751-764.

Mulyono, T. (2004). Teknologi Beton. Yogyakarta: Penerbit Andi.

Neville, A.M. (2011). Properties of Concrete 5th Edition. England: Pearson Education Limited.

Oktaviani, R. (2016). Penggunaan Bubuk Kulit Kerang Darah Dan Lokan Sebagai Bahan Pengganti Semen. Universitas Riau. Riau

Olivia, M. (2009). Durability of Low Calcium Fly Ash Geopolymer Concrete in Chloride Solution. Proceedings of the 6th Asian Symposium on Polymer in Concrete.

Olivia, M., Oktaviani ,R., Ismeddiyanto (2016). Properties of concrete containing ground waste cockle and clam seashells. Sustainable Civil Engineering Structures and Contruction Materials.

Olivia, M. (2011). Durability Related Properties of Low Calcium Fly Ash Based Geopolymer Concrete. Curtin University of Technology. 
Othman, N.H., Bakar, B.H.A., Don, M.M., Johari, M.A.M. 2013. Cockle Shell Ash Replacement for Cement and Filler in Concrete. Malaysian Journal of Civil Engineering

Permana, A.B. (2008). Pemanfaatan Limbah Cangkang Kerang Hijau. <URL: http://djail26.blogspot.com/2008/06/pemanfaatan-limbah-cangkang-kerang.html> [diakses: 23 September 2012]

Putra, M.A. (2014). Pemanfaatan Kombinasi Limbah Abu Ampas Tebu dan Abu Kulit Kerang Sebagai Subtitusi Semen Pada Campuran Beton Mutu K225 dengan NaCl Sebagai Rendaman. Universitas Sriwijaya.

Safi, B., Saidi, M., Daoui, A., Bellal, A., Mechekak, A., Toumi, K. (2015). The Use of Seashell As A Fine Aggregate (By Sand Substitution) in Self-Compacting Mortar (SCM). Construction and Building Materials.

Siregar, S.M. (2009). Pemanfaatan Kulit Kerang dan Resin Epoksi Terhadap Karakteristik Beton Polimer. Universitas Sumatera Utara.

Supriani, F. (2013). Pengaruh Umur Beton Terhadap Kuat Tekan Beton Akibat Penambahan Abu Cangkang Lokan. Universitas Bengkulu.

SNI 06-6825-2002. Metode Pengujian Kekuatan Tekan Mortar Semen Portland untuk Pekerjaan Sipil. Jakarta: Badan Standarisasi Nasional.

SNI 15-2049-2004. Semen Portland. Jakarta: Badan Standarisasi Nasional.

Syafpoetri, NA. (2013). Pemanfaatan Abu Kulit Kerang (Anadara grandis) Untuk Pembuatan Ekosemen. Universitas Riau

Tarisa, E. (2016) Durabilitas Beton Bubuk Kulit Kerang Di Lingkungan Air Laut. Universitas Riau. 


\section{CALL FOR PAPER}

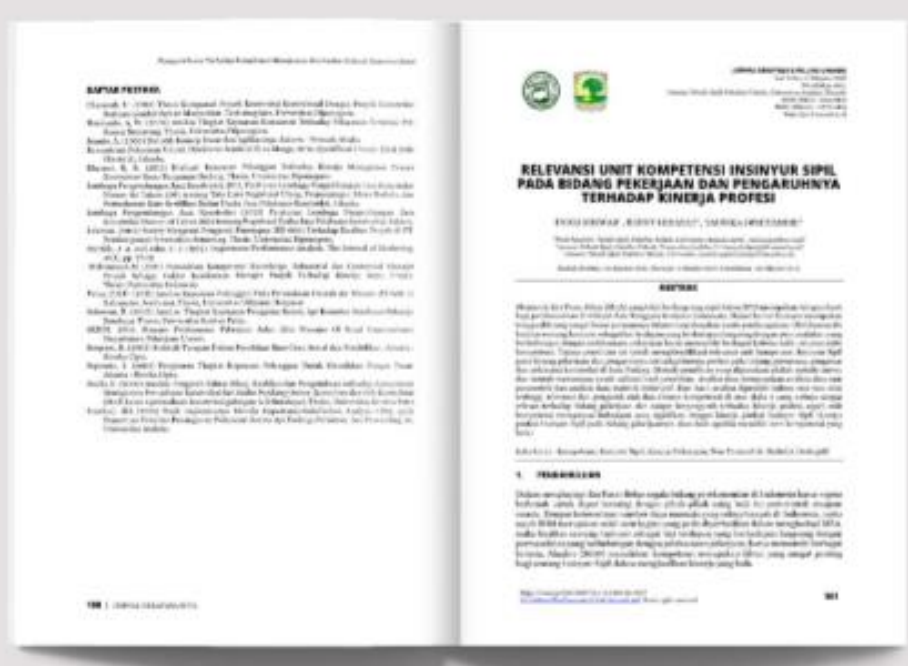

Jurnal Rekayasa Sipil (JRS-Unand)

Edisi 14(2) - Oktober 2018

Info : http://jrs.ft.unand,ac,id 